\title{
Agroecology: A Review from a Global-Change Perspective
}

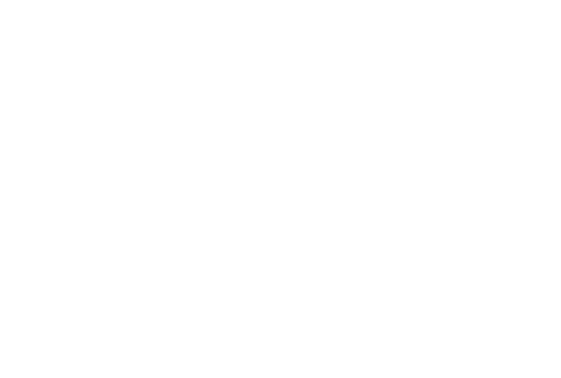

Annu. Rev. Environ. Resour. 2011.36:193-222

First published online as a Review in Advance on August 3, 2011

The Annual Review of Environment and Resources is online at environ.annualreviews.org

This article's doi:

10.1146/annurev-environ-012110-121302

Copyright (c) 2011 by Annual Reviews. All rights reserved

$1543-5938 / 11 / 1121-0193 \$ 20.00$
Thomas P. Tomich, ${ }^{1,2,3,4}$ Sonja Brodt, ${ }^{3,4}$

Howard Ferris, ${ }^{5}$ Ryan Galt, ${ }^{1}$ William R. Horwath, ${ }^{6}$ Ermias Kebreab, ${ }^{7}$ Johan H.J. Leveau, ${ }^{8}$ Daniel Liptzin, ${ }^{3,4}$ Mark Lubell, ${ }^{2}$ Pierre Merel, ${ }^{9}$ Richard Michelmore, ${ }^{10,11,12,13}$ Todd Rosenstock, ${ }^{3,4}$ Kate Scow, ${ }^{3,6}$ Johan Six, ${ }^{13}$ Neal Williams, ${ }^{14}$ and Louie Yang ${ }^{14}$

\footnotetext{
${ }^{1}$ Department of Human and Community Development, ${ }^{2}$ Department of Environmental Science and Policy, ${ }^{3}$ Agricultural Sustainability Institute at UC Davis, ${ }^{4}$ UC Statewide Sustainable Agriculture Research and Education Program, ${ }^{5}$ Department of Nematology, ${ }^{6}$ Department of Land, Air and Water Resources, ${ }^{7}$ Department of Animal Science, ${ }^{8}$ Department of Plant Pathology, ${ }^{9}$ Department of Agricultural and Resource Economics, ${ }^{10}$ Department of Molecular and Cellular Biology, ${ }^{11}$ Department of Microbiology and Immunology, ${ }^{12}$ Genome Center, ${ }^{13}$ Department of Plant Sciences, ${ }^{14}$ Department of Entomology, University of California, Davis, California 95616; email: tptomich@ucdavis.edu, sbbrodt@ucdavis.edu, hferris@ucdavis.edu, regalt@ucdavis.edu, wrhorwath@ucdavis.edu, ekebreab@ucdavis.edu, jleveau@ucdavis.edu, liptzin@ucdavis.edu, mnlubell@ucdavis.edu, prmerel@ucdavis.edu, rwmichelmore@ucdavis.edu, trosenstock@ucdavis.edu, kmscow@ucdavis.edu, jwsix@ucdavis.edu, nmwilliams@ucdavis.edu, lhyang@ucdavis.edu
}

\section{Keywords}

agrobiodiversity, agriculture, coupled social-ecological systems, human-environment interactions, nutrient cycling, resilience

\begin{abstract}
This review by a multidisciplinary team maps key components and emerging connections within the intellectual landscape of agroecology. We attempt to extend and preview agroecology as a discipline in which agriculture can be conceptualized within the context of global change and studied as a coupled system involving a wide range of social and natural processes. This intrinsic coupling, combined with powerful emerging drivers of change, presents challenges for the practice of agroecology and agriculture itself, as well as providing the framework for some of the most innovative research areas and the greatest potential for innovation for a sustainable future in agriculture. The objective of this review is to identify forward-looking scientific questions to enhance the relevance of agroecology for the key challenges of mitigating environmental impacts of agriculture while dramatically increasing global food production, improving livelihoods, and thereby reducing chronic hunger and malnutrition over the coming decades.
\end{abstract}




\section{Contents}

1. REFRAMING THE SYSTEMS PERSPECTIVE OF

AGROECOLOGY . .

1.1. Approaches and Definitions of Agroecology

1.2. Connecting Agricultural

Sciences and Environmental

Sciences

1.3. Connecting Agricultural

Sciences and Social Sciences..... 196

1.4. Agroecosystem Dynamics and

Resilience .................. 197

2. THE AGROECOLOGICAL NEXUS

2.1. Agricultural Production

Practices and Systems ......... 199

2.2. Agrobiodiversity

2.3. Agricultural Nutrient Inputs,

Outputs, and Pollution . .

2.4. Livestock Production Systems

and Their Impacts on the

Environment and Health

2.5. Cycling of Resources:

Nutrients, Energy, Water ....... 204

2.6. Food Access and Local Food

Systems .................. 206

2.7. Innovation Networks ......... 208

3. DISCUSSION AND PREVIEW OF

SOME EMERGING ISSUES .... 209

3.1. Agroecology, Global Change, and Human Values............ 209

3.2. Agrobiodiversity,

Biotechnology, and

Genomics ...

3.3. Belowground Agrobiodiversity

Management

3.4. Agricultural Inputs, Farming

Practices, and Transitions

between Systems .

3.5. Resilience and Integration of

Production Systems

\section{REFRAMING THE SYSTEMS PERSPECTIVE OF AGROECOLOGY}

\subsection{Approaches and Definitions of Agroecology}

Gradually over the past 30 years or more, often with inspiration from the practices, ideas, and questions of visionary farmers, academics increasingly have applied ecological insights to agricultural systems in a multidisciplinary field that has come to be known as agroecology (14). In their recent review of the evolution of this term since its emergence in the literature in the 1930s, Wezel \& Soldat (5, p. 3) observe that "at present, agroecology can be interpreted as a scientific discipline, as a movement or as a practice." Indeed, some academics in the vanguard of efforts to consolidate the science of agroecology in the 1980s and 1990s now place particular emphasis on extending those scientific foundations and agroecological practices as the basis for social movements aimed at fundamental transformation of agriculture, food systems, and society (M. Altieri, personal communication; S. Gliessman, personal communication). While accepting the legitimacy and importance of those movements for social change growing out of agroecology, this review (apart from Section 2.6 below) focuses primarily on agroecology from a scientific perspective. Our intention is to review the science of agroecology in light of emerging understanding of the challenges facing agriculture in the twentyfirst century, particularly regarding new insights from global-change science. Indeed, our specific objective is to identify critical elements of the next generation of scientific questions for the field of agroecology that will be relevant to these emerging twenty-first century challenges.

From a scientific perspective, agroecology has been defined by Gliessman (3, p. 369) as "the science of applying ecological concepts and principles to the design and management of sustainable food systems," emphasizing its roots in agronomy and ecology. Francis et al. (6, p. 100) provided a much broader definition of 
agroecology as "the integrative study of the ecology of the entire food system, encompassing ecological, economic and social dimensions." For our review, we adopted this broader definition in which society plays a fundamental role.

Thus, a key challenge within agroecology is to coherently understand manifold relationships and feedbacks across two broad cross-disciplinary boundaries that go beyond conventional perspectives on agricultural, environmental, and social sciences. One boundary to span is the connection between agricultural sciences and ecology and allied environmental sciences, which together provide the basis for understanding relationships between fieldlevel agroecological processes [e.g., pollination, biological pest control, nutrient cycling, carbon (C) sequestration] and broader environmental phenomena (e.g., habitat loss, eutrophication, climate change). Recent literature also draws attention to the equally important disciplinary boundary that has divided much of the agricultural and social sciences. Within this larger definition of agroecology, society and its various aspects play fundamental roles, shaping agriculture within a complex food system.

In their quantitative analysis of the field, Wezel \& Soldat (5) found that the scope of agroecology grew enormously over the past 20 years, and, in their words, the number of publications in the field has "exploded" since 2000. In an effort to cope with this rapid expansion, Section 1 of our review surveys the boundaries and context of the complex and expanding "intellectual landscape" of the science of agroecology. To obtain a workable focus within this broad field, the coauthors used an online polling tool to prioritize topics according to three criteria: (a) reviewability: the existence of a significant body of relevant refereed publications since 2005, which we used as the focal period for our review; (b) global food security: the potential over the next four to five decades for mitigating the environmental impacts of agriculture while increasing global food production and agricultural resilience; and $(c)$ priorities for future research. Topics with the highest scores are the subjects of Section 2, which emphasizes what we call the "agroecological nexus." A topic is considered to be within the agroecological nexus if there are well-established (or highly plausible) effects on agricultural production decisions or land use. For example, we consider concentration of food marketing to be within the field of agroecology because it can affect prices significantly and, in turn, shapes agricultural practices and investment decisions. Topics scoring high on the second and third criteria, but not on the first criterion, are nevertheless important parts of our preview of the field, are discussed in Section 3, and are summarized in the Future Issues section.

At this point, we also acknowledge that we have not been able to include the large and dynamic literature on agroecology that has been published in Spanish and Portuguese. Key ideas in the science and practice of agroecology emerged (and continue to emerge) in Latin America, and this certainly is a major gap in our review. For readers seeking an entry point to this rich literature, we have provided a link to the Web site for the Latin American Society of Agroecology in the Related Resources section; important current reviews for some additional topics not covered here also are suggested in that section.

\subsection{Connecting Agricultural Sciences and Environmental Sciences}

As with ecology, agroecology is concerned with energy flows, species interactions, and material cycling, but it also must address changes in agricultural production practices and stresses on agricultural systems from powerful drivers outside of agriculture. In particular, the impact of human activity on processes at continental and global scales-including, in no small part, the environmental impacts of agriculture itselfrequires that agroecology address a complex, dynamic, and increasingly uncertain context of multiple, interacting drivers of land-use change (7). Such drivers may test adaptive capacity and resilience of agricultural systems, raising possibilities of threshold dynamics that threaten
Food system (or agri-food system): interacting determinants of food access; of quantities and qualities of food supplied; and of food production, processing, marketing and distribution

Resilience: capacity of a system to recover its original structure and functions after a disturbance (see

http://www. resalliance.org/index. php/resilience)

Agroecological nexus: the convergence of social and environmental forces shaping agricultural and land-use decisions

Threshold: point of nonlinear change that alters system structure and functions, and can be difficult or impossible to reverse 
Agroecosystem: terrestrial ecosystem managed by humans primarily to produce food, but which also produces other goods and environmental services

Ecosystem services: goods and services people obtain from ecosystems agroecosystem functions and therefore food security. Traditionally, agricultural science has focused at the plot or field scale, whereas these societal and environmental concerns manifest at the landscape, state, national, continental, and global scales (8). Over the past decade, global-change science and international assessment processes have accumulated a great deal of evidence demonstrating the global significance of human influences on Earth's ecosystems, including the impact of agriculture on land-cover change and the supply of ecosystem services (9-11). In turn, large-scale environmental challenges, including potentially disruptive climate change (12) and regional water scarcity $(13,14)$, have implications for agricultural production and global food security.

Agricultural production processes and related ecosystem services thus are linked to local, regional, and global environmental phenomena, which, in turn, feed directly back to agricultural production. In light of this web of cross-scale relationships involving multiple drivers of change, agroecology must consider multiple spatial and temporal scales to develop and implement sustainable solutions. These spatial scales range from molecular to global. A similarly daunting range holds for temporal scales of inquiry, with processes manifesting themselves within a few hours to days, weeks, seasons, years, decades, ultimately centuries, and arguably millennia (15).

Within this wide menu of possibilities, there is a rapidly expanding body of ecological research at the landscape scale that is highly relevant to agroecology. Nevertheless, despite the rapid development of landscape ecology over the past 20 years, Turner (16, p. 336) concluded in her 2005 review that "much remains to be learned about ecosystem processes in heterogeneous landscapes," which includes agriculture. The same year, Kremen (17, p. 468) observed that "ecological understanding of ecosystem services is quite limited." Fortunately, work by Kremen and coworkers reviewed below in Section 2.2 has significantly advanced understanding of pollination ecology within a landscape context. Similarly, Ahrens et al. (18) have demonstrated how biogeochemical processes of fundamental importance to agroecology can be analyzed within agricultural landscapes, and Nelson et al. (19) have applied a spatially explicit landscape model to analyze trade-offs among biodiversity conservation, ecosystem services, and agricultural commodity production.

\subsection{Connecting Agricultural Sciences and Social Sciences}

Agriculture is fundamentally a human activity, created and adapted to meet social needs and shaped by culture and social structures (20). How the field of agroecology conceptualizes the nexus of agricultural science and social science depends, in turn, on the interpretation of the notions "environment" and "society," often also posited as "nature" and "culture." Although early paradigms of ecology and social sciences tended to view humans as independent of the natural world, more recent approaches conceptualize humans as embedded in the environment. In this view, there is no more "wilderness" or "nature" without people, and humans and their societies are shaped by and are shapers of landscapes and ecological processes, with agriculture as a prime example of these interactions. Understood thus, agriculture is a manifestation of cultural and social factors in relation with nonhuman environmental factors, and agroecology necessarily must connect agricultural sciences with both the environmental sciences and the social sciences, including economics.

Insights from social science, especially work in the environmental social sciences (21) and social sustainability (22), suggest that environmental problems are social both in definition and in root origin. Specific social configurations drive much environmental degradation and therefore must be modified for conservation and sustainability (23). In addition, Guthman (24) and Getz et al. (25) emphasize the point that particular groups' interests in environmental aspects of sustainability and agroecology are not necessarily matched by interests in social justice. 
As pioneered by Daily and colleagues (9) and implemented by the Millennium Ecosystem Assessment (MA) (10), the ecosystem services perspective provides one way to integrate social and environmental perspectives and consider ecosystem trade-offs from the perspective of human well-being (also see References 26 and 27). Agroecosystems provide ecosystem services, the most obvious is provisioning of food, and benefit from services associated with other surrounding ecosystems, including water supply, pollination, and pest control. In turn, agriculture may negatively affect the services provided by those surrounding ecosystems (28). Measuring how agriculture differentially affects different ecosystem services requires appropriate frameworks and indicators to account for costs and benefits. Inevitably, the questions then become: Who values the alternatives and how?

The related questions of social justice and power within society-that is, who makes decisions on important issues like environmental valuation and social trade-offs and by what rules, and who decides on the rules-are central to the question of sustainability and therefore must be considered in agroecology. Food and agri-input industries act within a marketplace nominally established and regulated by the state, over which they often have considerable influence. As such, despite the traditional focus of agroecology on farmers and their practices, Levins (23) stresses that understanding of these firms and other powerful private interests and their relationships to public policy is necessary when considering changes within the system. These questions of social structure and agency (29), and the interplay of the state, private enterprise, and civil society, are central to understanding prospects for agricultural sustainability. Institutions also shape science and technology, so the research agenda of agricultural science, including agroecology, must be seen as socially constructed. Thus, fundamental values regarding human dignity, social justice, equity, economic opportunity, and environmental stewardship, as well as the principles and processes governing society's choices, also are important subjects and practical challenges for any discipline concerned with sustainability $(22,30)$.

Of course, understanding and creating the conditions necessary for an idealized state of social justice is a daunting agenda. A separate strand of literature is concerned with incremental progress toward greater social justice (31). A pragmatic approach, of particular relevance to agroecology, has emerged that, among other considerations, focuses on establishing greater legitimacy in processes linking knowledge with action for improved ecosystem management, with governance, accountability, and participation in agenda framing as some of the key points of interest $(32,33)$.

\subsection{Agroecosystem Dynamics and Resilience}

Agriculture epitomizes the complex humanenvironment interactions that now are conceived and studied as "coupled socialecological systems" $(34,35)$. The study of coupled systems and other areas of globalchange science shows how environmental and social sciences play complementary roles in understanding contemporary challenges to food system sustainability, environmental integrity, and resilience (36). Resilience is integrated across many scales in agricultural systems and is linked to biological and social diversity at multiple scales. Integration of social science is essential to understand and enhance resilience of Earth's agroecosystems in the face of complex cross-scale interactions (37) and also to identify thresholds of concern (38). Insights from the literature on resilience are applicable at the farm scale (39), but Brondizio et al. (37), Elmqvist et al. (38), and Lebel et al. (40) all stress that any effort to address resilience at scales beyond the enterprise or household level must additionally confront issues of governance.

Pressures on agriculture to increase food supply while minimizing environmental damage and social disruption are likely to continue to intensify in the coming decades, with continuing growth in human population at least
MA: Millennium

Ecosystem Assessment 
through mid-century and shifting patterns of demand-especially for livestock productsdriven by rising income in some regions. There are suggestions that the absolute numbers of hungry people are once again increasing globally, which would be a reversal of gains in recent decades $(11,41,42)$. The future also holds great uncertainties regarding climate change and energy prices, which compound familiar sources of agricultural production risk, involving yields, water supplies, synthetic fertilizer prices, pests, and diseases.

Liu et al. (34) and other theorists and empiricists suggest thresholds of critical change are likely features in the dynamics of these coupled systems. The MA (10, p. 1) did find "established but incomplete evidence" that changes in ecosystems generally are "increasing the likelihood of nonlinear changes... including accelerating, abrupt and potentially irreversible changes." Species invasions are one tangible example of abrupt, essentially irreversible change (43), typically bringing adverse consequences for agriculture.

It seems clear that agroecology holds particular promise in assessing vulnerability and resilience of agricultural systems and in identifying thresholds of concern regarding food supply. However, as pointed out by the MA, although science can identify risks of nonlinear change, "it cannot predict the thresholds where the change will be encountered" (10, p. 11). Indeed, we currently lack monitoring capability for the most basic assessment of agricultural systems at policy-relevant scales (44) or for integrated observation of most forms of regional and global environmental change (45). Rockstrom et al. (46) proposed tentative planetary thresholds for some issues directly linked to resilience of global agriculture [climate, nitrogen $(\mathrm{N})$ and phosphorus $(\mathrm{P})$ cycles; freshwater use; biodiversity loss]. In light of limitations in both methods and data, it is perhaps inevitable that these thresholds would be questioned, but it also is noteworthy for this review that Rockstrom et al. argue that planetary boundaries already have been crossed regarding climate change, rates of biodiversity loss, and $\mathrm{N}$ loading. The apparent vast inequalities in adaptive capacities (globally and within societies) mean that the impacts of crossing thresholds will not be felt equally. As a result, these changes are likely to increase inequality and, thereby, also may contribute to social instability.

\section{THE AGROECOLOGICAL NEXUS}

In this section of our review, we consider seven interrelated sets of topics that we selected because they have received considerable attention from researchers in recent years and, as a result, significant numbers of scientific publications exist. As mentioned in Section 1.1, above, we have used the notion of an agroecological nexus as a means to focus this review. Although this device does help set boundaries for our review, these limits remain very broad because we take the position that the scientific field of agroecology must consider the domain of well-established (or highly plausible) phenomena that shape agricultural production decisions or land use.

Rather than cataloging practices and systems as agroecological or not, we instead have attempted to further process-based understanding of agricultural practices informed by agroecological perspectives in Section 2.1, below. On par with practices and systems, the topic of agrobiodiversity also has been a mainstay of the agroecological literature and spans many different aspects of ecosystem functions and services. In our approach to agrobiodiversity in Section 2.2, we illustrate many of the concepts and principles associated with ecosystem services in relation to agrobiodiversity by focusing on just two of the myriad possible examples, pollination and the biological regulation of soil pests, especially nematodes. We also use those examples to explore the management opportunities and challenges involved in conserving and restoring such services. Next, we turn to three interrelated sections that involve some of the greatest agroecological contradictions in contemporary agriculture: Section 2.3 on nutrient inputs to cropping systems and Section 2.4 on 
livestock systems and their impacts. We attempt to bring these issues into our broader consideration of resource cycling in Section 2.5.

As we argued in Section 1.3 above, our position is that methods and issues from social science (including economics) are as important to agroecology as are the more conventional agroecological approaches that are based on agricultural, ecological, and environmental sciences. Creating a truly interdisciplinary (or transdisciplinary) field of agroecology remains a work in progress, and the recent literature still is heavily weighted toward the agricultural, ecological, and environmental perspectives. However, there is a flourishing literature on food systems, and we turn to that aspect of social science contributions to the field of agroecology in Section 2.6, emphasizing food access and local food systems. Before proceeding to Section 3 with our views on emerging issues, we conclude Section 2 with consideration of innovation networks in Section 2.7, which is another area of social science research that produces key insights on agroecosystem dynamics and practical approaches to increasing adaptive capacity and resilience in agriculture and the food system.

\subsection{Agricultural Production Practices and Systems}

There is a huge range of global variation in farming systems and in agricultural productivity. Although the authors of this review share an interest in tropical agriculture, our review of the recent literature perhaps inevitably is skewed toward cropping and livestock systems in the temperate regions and cannot adequately cover the particulars of agroecology in a full range of regional contexts. Although a separate review probably would be required to do complete justice to these systems, such as agroforestry, we wish to point to a small, indicative sample of recent publications relevant to tropical agroecology. For example, the volumes on "ecoagriculture" by Scherr \& McNeely (47) and on "alternatives to slash and burn" by Palm et al. (48) provide important synoptic views of agroecological issues from a global perspective.
At the regional level, we already have acknowledged the gap in our coverage of the essential Latin American literature on agroecology in Section 1.1. The important recent publications in English for Mesoamerican agroecology include DeClerck et al. (49) and Harvey et al. (50). For sub-Saharan Africa, Pretty et al. (51) report on an impressive set of agroecological success stories, and Garrity et al. (52) focus on promising agroforestry practices in various parts of Africa. From a somewhat different perspective, Tomich et al. (53) consider the policy issues related to agricultural practices, land use, and environmental services in Southeast Asia.

Abstracting from this wide regional and local variation, the twentieth century nevertheless saw pronounced trends toward specialization and intensification in use of purchased seed, fertilizer, pesticides, fuel, and other commercial inputs, including many derived from petroleum or natural gas. Particularly since World War II, this intensification has significantly increased productivity and has transformed farming on a large share of the planet. From 1960 to 2000, while food production more than doubled and food supply per capita increased almost everywhere (save sub-Saharan Africa), biologically available $\mathrm{N}$ flows doubled in terrestrial systems, and flows of $\mathrm{P}$ tripled as a result of agricultural activities. Over half of all $\mathrm{N}$ fertilizer ever manufactured has been used since 1985 (10). In a broad sense, the intensive use of chemical inputs and fossil energy can be viewed as substitution of petroleum and natural gas for ecological functions and labor. Specifically, purchased inputs have substituted for local recycling of resources, particularly manures in integrated crop-livestock systems, and for crop rotation sequences that promote biological $\mathrm{N}$ fixation or suppress pests and diseases. The low cost of $\mathrm{N}$ fertilizer and transportation, both dependent on fossil energy (petroleum and natural gas) prices, facilitated specialized farming, which, in turn, led to loss of landscape biodiversity as the patchwork of differently cropped land disappeared in many regions. Agrobiodiversity also has been lost through 
CAFO: concentrated animal feeding operation

IPM: integrated pest management specialization in higher-yielding varieties (54) and the requirement by processors and retailers for standardization of cultivar characteristics. The same forces enabled the livestock component of agriculture to be divorced from crop production (55) as specialized producers favored large concentrated animal feeding operations (CAFOs). From an agroecological perspective, biodiversity loss and dependency on petroleum and natural gas, coupled with rising uncertainty about energy prices and climate change, lead to increased vulnerability and decreased resilience of the whole system (11).

\subsection{Agrobiodiversity}

Productivity and resilience in many ecosystems are variously correlated with spatial, temporal, and genetic diversity. The ecological services provided by greater diversity of crop species, genotypes, and habitats within the agricultural landscape may enhance soil nutrient cycling, mineral retention, and regulation of pests and pathogens, and improve pollination and water quality $(56,57)$. The enhancement and conservation of biodiversity are interwoven throughout these processes and are integral components of biological control and integrated pest management (IPM) (58). Although the abundance of individual species in a diverse community may vary in relation to the adaptation of each to prevailing conditions, year-toyear resilience of biomass and yield is enhanced by genetic diversity and species richness (59, 60). Through its effects on reducing concentrations of food sources and habitat for pests and diseases, genetic diversity provides resilience to biotic stress, such as plant pathogens and arthropod pests $(61,62)$. Rotation of crop genotypes generates biodiversity at a temporal scale, with definable impacts on soil health, nutrient status, and soil-inhabiting pests and beneficial species. Maintenance of vegetation refugia for beneficial insects and for natural enemies of more motile pest species represents spatial biodiversity in agricultural systems $(56,63)$.

In addition to the variety of animals and plants that are the direct products of agriculture, agrobiodiversity includes the diversity of nonharvested species that support production (soil microorganisms, predators, pollinators) and those in the wider agricultural, pastoral, forest, and aquatic environments that support agroecosystems. However, of the approximately 7,000 species of food crops currently under cultivation (64), only 103 plant species represent $90 \%$ of global food production (65). Clearly, vast areas of the agricultural landscape are in spatial and temporal monoculture. Agrobiodiversity has been greatly reduced by land management practices that include hedgerow removal, clearing of natural vegetation to expand field size, land leveling, intensive tillage, pesticides, mineral fertilizers, clonal propagation, and planting of extensive monoculture. Such practices maximized productivity with scant regard for environmental consequences and, in some cases, product quality. Practices designed to minimize ecosystem disservices, including the impacts of pests and diseases, often inadvertently diminish many ecosystem services.

Shea \& Chesson (66) argue that reestablishment of diversity in agroecosystems requires an understanding of niche opportunity as determined by a conducive environment and the occurrence and variability in time and space of both resources and biological regulators. This involves the core phases of invasion biology: arrival, establishment, integration, and spread, although these are usually documented in relation to harmful species that provide ecosystem disservices $(67,68)$. Organisms with a broader geographic range and ecological amplitude are more likely to become established in a new environment. The elimination or reduced usage of agricultural chemicals is conducive to the successful establishment of natural enemies of pest species; a variety of plants and organisms provides refugia, sources, and nurseries for biological control agents. For example, Cook et al. (69) document how designed spatial patterns of plant species comprise elements of "push-pull" strategies whereby visual and chemical cues, and predation pressures, create an unfavorable ambience for pest species in a susceptible crop 
while providing the lure of an alternative favorable environment.

Shifting our attention from pest control to services provided by insects- the biodiversity of bees is an important component of both the level of crop pollination and its stability over time (70, 71). Kremen et al. (70) demonstrate how wild bee populations contribute substantially to this ecosystem service. Winfree et al. (72) show how these wild populations often are negatively affected by loss of natural habitat and other practices associated with agricultural intensification. Bee populations persist where sufficient floral and nesting resources are available. Large crop monocultures may offer no flower rewards, as in the case of cereals, or provide only a short-duration pulse of floral reward, as with mass-flowering crops like canola, sunflower, and squash. Bees are mobile organisms that can gather resources from different habitats (73). Although mass-flowering crops can benefit individual species (74), the diversity of natural habitat provides more consistent floral and nesting resources that are absent from intensively managed agriculture. Remnants of native vegetation, or farming practices that promote diverse flower communities through polyculture or maintenance of noncropped areas, can provide extended bloom periods that enhance pollinator abundance and diversity (75). Such habitats also offer nesting opportunities for bees $(76,77)$. Pulliam (78) provides the important caveat that small habitat elements providing modest resources potentially represent sinks that attract bees but may not support their populations in sufficient abundance to provide adequate pollination.

The scientific study of belowground agrobiodiversity has seen great advances over the past decade. As an example, we consider soil nematodes, which are aquatic organisms inhabiting the water films surrounding soil particles. They are exposed to pesticides, fertilizers, and other materials applied to the field, where the compounds dissolve and become concentrated in the soil solution. Some nematodes are less tolerant of these agrochemicals than other nematode species (79). Functional groups of nematodes occupy several trophic levels in the soil food web. Herbivorous species are primary consumers of plant material, and bacterivores and fungivores occupy secondary positions in decomposition channels, whereas generalist and specialist predators represent the potential regulators of opportunistic species at the entry level of the food web (80). Predatory nematodes are generally larger than their prey and are more sensitive to the stressors of conventional agriculture. They have low fecundity and relatively slow development, so their recovery from perturbation is extremely slow $(81,82)$. Furthermore, predatory nematodes are bioindicators of other organisms with similar ecosystem functions, including mites and collembola, and with similar sensitivities to environmental perturbation (83). Consequently, the highly fecund taxa at lower levels in the food web increase with little biological regulation (84). Root-feeding species often achieve pest-level abundance, which, in conventional management systems, is often resolved by intervention with soil fumigants and other pesticides. That, in turn, increases negative pressure on the invasion or reestablishment potential of regulatory species.

Reestablishment of the soil food web to promote its ecosystem services belowground poses challenges and opportunities in the redesign of both production systems and inputs. Early work by Jensen \& Mulvey (85) showed how predator nematodes absent from agricultural fields may be common in surrounding uncultivated areas. If the factors that have negative impacts on higher trophic levels of nematodes in agricultural fields are removed, how much time is required for functional reestablishment of predators? Migration among metapopulation patches of prey species in the three-dimensional matrix of the soil is a slow process. Although some species of predatory nematodes can be multiplied on bacteria (86), most would be difficult to rear in large numbers for field release, and few survive mechanical incorporation into soil. One possibility warranting further exploration is the plugging 
of cores of soil from undisturbed locations into the agricultural field under remediation.

Collocation of predators and prey in the soil matrix is a key consideration for restoration of belowground communities. Bacterial- and fungal-feeding nematodes aggregate around organic residues near the soil surface. Predators exploiting them as a resource may not come into contact with species that feed on plant roots. Tillage to incorporate organic matter into soil may be detrimental to the predators and alter root distribution. Possibilities for enhancing collocation of predators and prey include mulching organic residues on the soil surface rather than incorporating them, irrigation practices that promote root concentrations in relation to water sources, and using heirloom cultivars with root architectures adapted to exploiting resources at the soil surface. Where some tillage or soil disturbance is necessary to place seed at an appropriate depth or to remove weeds from the plant row, minimizing the size of the tilled strip should maximize survival of sensitive species in the proximate nontilled zone. The challenge is to engineer the system so that it is conducive to functional establishment of higher trophic levels and facilitates collocation of predators and prey.

Clearly there are scale components to these two highlighted examples, bees and nematodes. The diverse organisms that provide ecological services in agriculture are regulated by factors operating at different spatial and temporal scales. At the landscape level, hedgerows may provide refugia for beneficial insects, while, within the field, cover crops in orchards may provide a wealth of ecological services. At the interplant level, combinations of genotypes may slow progression and severity of plant disease epidemics (87). At the plant level, rhizosphere bacteria and mycorrhizal fungi can be applied uniformly to seedling roots at transplanting $(88,89)$. Temporally, crop rotation sequences can be designed to build soil fertility, break disease cycles, amplify natural enemies, and accelerate the decline of pest species. Although native bee pollinators are highly mobile and integrate elements of the landscape at scales of hundreds to thousands of meters, beneficial soil micro- and macrofauna are relatively immobile, and their unaided spread may be measurable only in decades (82). Some strategies for future sustainability may, by serendipity, benefit different types of organisms and the services they provide; however, there will more often be a need for integrated strategies that explicitly balance needs of different species and services. Governmental assistance may be necessary to offset costs on an individual basis for benefits at a landscape level (90). The enduring challenge is the search for practices that simultaneously provide greatest breadth of ecosystem services.

\subsection{Agricultural Nutrient Inputs, Outputs, and Pollution}

Nitrogen is the limiting element for plant growth in many agroecosystems. The HaberBosch ammonia synthesis process, one of the hallmark scientific achievements of the twentieth century, enabled mitigation of this $\mathrm{N}$ limitation. The process uses fossil fuels under high temperatures and pressures to reduce $\mathrm{N}_{2}$ from the atmosphere to ammonia, a reactive form of $\mathrm{N}$ that can be utilized in various forms of fertilizer. Although N fertilizers enabled crop production levels high enough to feed the world's population, their usage resulted in unintended releases of reactive $\mathrm{N}$ to the broader environment through agricultural runoff, trace gas emissions, and additional human sewage production (91, 92). Bouwman et al. (93) argue that soil $\mathrm{N}$ imbalances, leaching, and denitrification are unlikely to decrease by 2050 even in the most optimistic projections for agricultural practices; worst-case scenarios for the current century picture what Erisman et al. (94) call a "nitrogen-saturated planet."

Phosphorus pollution is a major problem in the developed world, but soil $\mathrm{P}$ availability limits crop growth in the tropics. There is increasing concern about the limitation of $\mathrm{P}$ availability. Gilbert (95) predicts that current reserves can sustain food production for another 50 to 100 years, depending on the environmental and economic constraints 
of extracting those reserves. Consequently, phosphate prices may rise, but that will create incentives for discovery of new reserves and for innovation in recovery of phosphates from waste. The recycling of $\mathrm{N}$ and $\mathrm{P}$ (at the farm and regional scale), improving efficiencies of $\mathrm{N}$ and $\mathrm{P}$ applications, and relying on natural sources are important elements of an agroecological agenda that we revisit below.

The issues discussed above point to the need for quantifying the extent to which agricultural management practices affect production and environmental outcomes. Farmers are the key decision makers with respect to land-use and management options. The constraints they face, in terms of output and input prices, as well as resource availability and policy, shape production and environmental outcomes. It is necessary to design policies that mitigate the adverse impacts of agriculture on the environment while sustaining livelihoods and ensuring food security. The complexity of these issues has stimulated efforts in bioeconomic modeling. A worldwide model of agricultural markets to analyze the greenhouse gas (GHG) consequences of U.S. ethanol policy predicts that encouragement of corn-based ethanol production will nearly double GHG emissions over 30 years as farmers expand production in response to higher crop prices (96). Various studies have coupled biophysical and economic models to derive opportunity cost curves for GHG reductions in agriculture through changes in land-use and management practices (97-99).

\subsection{Livestock Production Systems and Their Impacts on the Environment and Health}

We now turn from cropping to the livestock subsector, before a broader consideration of nutrient flows and other cycles in Section 2.5. Bringing livestock into consideration is crucial. For example, about half of the grains produced in the United States, and the $\mathrm{N}$ used in their production, is fed to animals for meat and dairy production. Animals only utilize about $30 \%$ of the $\mathrm{N}$ ingested; the rest is deposited as feces and urine in manure. Typically about $50 \%$ of manure $\mathrm{N}$ is lost during collection, handling, and land application, particularly through ammonia volatilization. $\mathrm{N}$ from both manure and synthetic sources leaches into groundwater or is lost in surface runoff. Return of manure to crop fields is easier in diversified agriculture than in spatially decoupled systems of animal agriculture and feed grain production.

Similarly, environmental and economic benefits can result from optimizing livestock $\mathrm{P}$ utilization (100). In swine production, $\mathrm{P}$ is often fed in excess of animal requirements to compensate for the relatively unavailable phytate $\mathrm{P}$ in grains; the excess is excreted and contributes to environmental pollution. Analysis by Kebreab et al. (101) suggests a combination of low-phytate crops and inclusion of phytase would be effective in reducing or eliminating supplementation of inorganic $\mathrm{P}$ in animal diets. Overall, the agroecological implications of resource conservation and reduction of soil and water $P$ pollution could be substantial.

Livestock production also contributes to anthropogenic GHG emissions (102), although the magnitudes are contested $(103,104)$. Comparative data are sparse, but to cite one available example, Pelletier et al. (105) conducted a comparative life cycle assessment study in the U.S. Upper Midwest and found pasturefinished beef to have higher GHG emissions, eutrophying emissions, and cumulative energy use than feedlot-finished beef. Peters et al. (106) found similar results applying life cycle assessment in Australia: the GHG emissions of grainand grass-finished beef estimated in that study were, respectively, 5.9 and $7.2 \mathrm{~kg} \mathrm{CO}$ equivalent $/ \mathrm{kg}$ animal weight. Yet they also presented data that red meat production in Africa in a pastoral system produces $5.0 \mathrm{~kg} \mathrm{CO}$ equivalent $/ \mathrm{kg}$ animal weight, whereas the value is four times greater in the intensive systems of Japan (106).

The main source of GHG emissions from livestock is enteric fermentation from ruminants, and these emissions are affected by diet quality; grain is more easily digested than forage. Although it is not clear whether reduced enteric methane emissions from a grain diet 
typically offsets GHG generated in production of the grain, Beauchemin et al. (107) review several promising strategies to reduce enteric methane production in ruminants through nutritional management. Godfray et al. (41) also suggest it may be possible to design systems that reliably reduce net GHG emissions. Herrero et al. (108) emphasize that extensive mixed crop-livestock systems, particularly in developing countries, could significantly contribute to future food security. Overall, Steinfeld \& Wassenaar (102) argue it seems inevitable that more intensive crop-based livestock systems will expand globally in the twenty-first century, while Gill et al. (109) conclude that available data are insufficient for quantifying the consequences of GHG emissions and the contribution of livestock products to global food security as production systems change. In short, there is little or no scientific consensus on the sustainability of trajectories of various livestock production systems.

In closing this section, it is important to note that microbial resistance developed from use of antibiotics in intensive livestock production systems is a growing concern globally because it undermines effectiveness of drugs that are essential to human health (110). The European Union banned nontherapeutic use of antibiotics in animals in 1999 owing to evidence of growing resistance. In veal, beef, and dairy herds, $72 \%$, $22 \%$, and $18 \%$ of animals, respectively, are reported resistant to at least one antibiotic (111). Duff \& Galyean (112) suggest that nutritional manipulation and use of directly fed microbial agents could be effective alternatives in preventing bovine respiratory disease in cattle. Antibiotic use in humans and agriculture also affects the ecology of soil and water bacterial communities. Novel methods for minimizing proliferation of resistant bacteria while meeting therapeutic and economic needs require collaboration among medical, veterinary, and horticultural users (113). Yet beyond these adjustments to existing systems, much additional research is needed to understand the scope for alternatives to CAFOs, such as grass-fed cattle and other systems, to meet growing global meat demand (and at what price for livestock products). Moreover, scientific collaboration is unlikely to be sufficient: Barza et al. (114) argue that there is a critical need for policy development regarding use of antibiotics; this is true for many other issues related to livestock production.

\subsection{Cycling of Resources: Nutrients, Energy, Water}

The intensive management in agricultural production systems dramatically affects the flow of energy, water, and nutrients within an ecosystem (115). Although the application of nutrients, particularly $\mathrm{N}$ from fertilizer and manure, and water via irrigation have fueled huge increases in food and fiber production, the export of resources through harvest disrupts natural flows $(2,116)$. Management changes both the relative and absolute magnitude of these flows. The quantity of $\mathrm{N}$ flowing through agroecosystems is significantly larger than in natural ecosystems, and the relative magnitude of fluxes of gaseous emissions, leaching, and harvest also are increased.

The physical and chemical disturbances associated with land management, such as frequent tillage and pesticide applications, alter soil structure and belowground communities (92). The net effect of management is that biogeochemical processes responsible for ecosystem function are disrupted, replaced, or superseded by agricultural practices and inputs in agroecosystems (see Section 2.2).

Although solar energy is still the source of energy for $\mathrm{C}$ fixation by plants, much of the human and animal labor in agriculture has been replaced by machines requiring fossil fuels (117). Huge tracts of land have become arable because of the expansion of irrigation in arid regions; fossil fuels are used to pump water from deep underground or across vast distances. The $\mathrm{N}$ fixed by symbiotic biological processes has been surpassed by synthetic fixation from the HaberBosch process (94). Complex rotations, cover cropping, and nutrient recycling have largely been replaced by synthetic fertilizer (60). 
Many of the tools and practices developed over millennia have been replaced over the past century by methods dependent on inexpensive fossil fuels. This section focuses on $\mathrm{N}$ as an example, but similar principles apply to energy, water, and other nutrients, as well as to their interactions.

Typically, 50\%, but sometimes even more, of applied synthetic $\mathrm{N}$ is lost to the environment as gaseous emissions to the atmosphere, leaching to groundwater, and runoff to surface waters $(91,92,117)$. For example, Galloway \& Cowling (118) estimate that $47 \%$ of all synthetic $\mathrm{N}$ fertilizer is lost at application in the field, and a further $6 \%$ is lost prior to use. Overall, their estimates (based on a representative omnivorous diet) suggest only $4 \%$ of total $\mathrm{N}$ fertilizer is directly consumed by humans (this rises to $14 \%$ for a vegetarian diet). It should be noted that these calculations do not account for $\mathrm{N}$ recovered through use of manure or crop residue in subsequent agricultural production. However, such practices have diminished greatly through specialization; in particular, animal manure has shifted from being a source of soil fertility to being primarily a waste disposal problem (92).

Global inequities in the availability and affordability of nutrients led to pollution in some regions of the world and a paucity of nutrients in other regions $(94,116)$. The losses associated with the inefficiencies in the system affect both environmental and human health in myriad ways, including coastal eutrophication, drinking water contamination, smog formation, and climate change (90, 119). Although improvements are possible in nutrient management, there may be biophysical thresholds that once crossed lead to unacceptable environmental change (46). We believe the key to addressing these challenges is to develop a comprehensive, ecologically based understanding of nutrient management.

New initiatives in managing resource cycling apply principles of ecology to identify and develop practices that are efficient yet minimize environmental degradation (20, 120). Ecological management can be viewed in larger context as providing but also utilizing ecosystem services. A systems orientation, built on a mechanistic understanding of process, is a shift from traditional approaches that maximize crop production through conventional fertilizers and crop variety improvement. The agroecological systems approach facilitates nutrient management at multiple temporal and spatial scales, including off-farm impacts. Traditionally, the focus of agricultural research and management has been at the field scale and usually entails short-term (one-to-three-year) studies. Such a lens is unlikely and unable to support a food system capable of providing the full range of ecosystem services increasingly demanded by society (121). Having too narrow a focus ignores the benefits provided by adjacent ecosystems and promotes decisions that, despite having localized benefits at the plot scale, may have adverse impacts at the other scales $(28,56)$. Advances in agroecological research, and in agricultural research more generally, depend on the integration of ideas from soil pores to plants, to people, to landscapes, and to bioregions, and at longer temporal scales $(121,122)$.

Strategies to improve utilization and reduce losses of existing nutrients can be based on the positive and negative interactions and feedbacks among taxa of organisms and between biological and abiotic processes (123). One approach to managing the key biogeochemical and hydrologic processes that occur at the molecular to soil-pore scale is to shape the biodiversity of the aboveground and belowground communities. A simple example is the use of practices that enhance beneficial mycorrhizal fungi while lessening reliance on phosphate fertilizers $(89,124)$. Other promising directions include harnessing soil biological processes to compensate for external nutrient inputs, repair soil structure, suppress plant diseases, and increase uptake of essential micronutrients for humans $(57,88,125)$. Increasing crop complexity within a field or over time can facilitate ecological interactions within agroecoystems and between agricultural and unmanaged ecosystems (126). More complex crop rotations that include crops (such 
as safflower) that scavenge for available $\mathrm{N}$ can reduce environmental $\mathrm{N}$ losses (127), although there may be trade-offs in farm profitability. The decreased profit associated with growing less profitable crops in rotation sequences could be compensated through incentives based on improvements in other metrics of ecological and social sustainability $(61,128)$.

An agroecological approach considers farms and fields within a broader landscape context to manage resource flows. Fields are often adjacent to rivers and other riparian areas, roads, and, increasingly, human settlements. The unintentional losses of $\mathrm{N}$ to surrounding landscapes can lead to localized eutrophication of water bodies, contamination of drinking water wells, and odor issues (129). However, analysis by Gascuel-Odoux et al. (130) shows how agricultural landscapes can be modified to protect water quality by using farm ponds, ditches, engineered catchments, wetlands, and adjacent unmanaged areas to catch, and even treat, irrigation water and runoff. Agroecological management of resource cycling also requires a perspective that extends beyond fields and their immediate surroundings. Improved management of tile drainage discharge could prevent not only the localized impacts of $\mathrm{N}$ on stream ecosystems, but also would dramatically improve the health of the Mississippi River and Gulf of Mexico (131).

The fate of fertilizers applied to farm fields extends far beyond the local agroecosystem because harvested products are transported to feed humans and livestock often at great distances from the site of nutrient application (132). Naylor et al. (55) suggest one promising approach to offsetting spatial nutrient imbalances is to "close the loop" by reintegrating animal and crop production systems as well as recycling the nutrients in human waste. Animal manure has been used as a source of plant nutrients for centuries, but as animal production systems have become more concentrated, manure becomes more a waste problem than a viable nutrient resource (102). Use of wastewater, a source of both nutrients and water, and composted sewage sludge as biosolids could provide nutrients for crops while minimizing nonrenewable fertilizer costs and reducing waste disposal costs and environmental impacts. However, there are agronomic and environmental challenges to recycling nutrients in waste. The low but variable $\mathrm{N}$ content and imbalanced N:P ratios of biosolids and manure create challenges in fertility management. These waste products are bulky and expensive to transport $(133,134)$. Furthermore, contaminants (e.g., personal care products, pharmaceuticals, heavy metals, nanoparticles) often become concentrated in biosolids and wastewater (135), suggesting that much broader ecological thinking about the entire materials economy is needed to allow for closing the loop.

Agroecological management of energy, water, and nutrients relies on a wide menu of practices developed through a holistic view of resource cycles (115). These practices also can enhance biodiversity and connect farms with the broader landscape at multiple spatial and temporal scales (121). Understanding the dynamics and drivers of the biological and physical processes that govern the availability of nutrients provides the foundation needed to reduce external inputs and improve efficiency. Eliminating external inputs while maintaining crop yield is unrealistic (117), so careful assessment of inputs and management to both add (manure, wastes, legume cover crops) and retain (cover crops, C sequestration, water management) nutrients is necessary to ensure adequate nutrient availability. In an agroecological approach, improvement in resource management seeks to balance these environmental, social, and economic costs and benefits.

\subsection{Food Access and Local Food Systems}

In addition to well-established interest in longterm productivity and the reduction of negative environmental impacts, issues of equity and social justice are increasingly topics of social science research on food systems that are relevant to agroecology (136). One of these topics of interest is food security, a concept first defined at 
a UN conference during food crises of the early 1970s and later adopted by various governments to apply at the individual level. The U.S. Department of Agriculture defines food security as a condition in which all people at all times have enough access to food for a healthy, active life. At a minimum, food security concerns the ready availability of nutritionally adequate and safe foods as well as the assured ability to acquire acceptable foods in socially acceptable ways, for example, without resorting to emergency food supplies, scavenging, stealing, and other coping strategies (137). Current developments related to food security in the industrialized world, exemplified by the United States, include $(a)$ the growing urban agriculture movement (138), including largely unregistered increases in household food production; (b) high levels of farmworker food insecurity $(139,140)$, despite their having the skills and knowledge to grow their own food; and $(c)$ the recent "Great Recession" resulting in the highest levels of food insecurity (14.7\% of U.S. households) since measurement began in 1995 (141).

The extent to which studies of food security and agroecology merge currently is a function of the structure of the food system. The more extenuated the food system (i.e., the more distinct stages, such as processing, distribution, retail, and others) through which food passes, the less attention it has received by agroecologists. In industrialized nations, food security is commonly perceived as disconnected from field-level and landscape-level ecological concerns. By contrast, agroecologists directly address food security issues in peasant communities, where farming households continue to grow much of their own food while being integrated into international markets (142).

There also is interest in identifying the effects of agrarian structure on the environmental and social impacts of agriculture. More specifically, there is a need to clarify some of the material differences between small- to mid-scale farming operations supplying local markets and those supplied by national or international food networks. One example is the energy intensity and GHG emissions embod- ied in food. Research has focused on whether locally grown foods result in less GHG emissions and energy consumption than nationally or internationally grown alternatives (143145). In their review in this volume, Pelletier et al. (146) find that the distances food is transported (often called "food miles") often are relatively much less important than commonly assumed. Yet another example is the food safety attributes of fresh produce: Are there differences in food safety between small, local produce growers and large, capital-intensive operations? In identifying these differences, attendant questions are whether existing local food networks are sufficiently provisioning locally grown foods through existing market channels, such as farmers' markets, communitysupported agriculture, and local procurement policies. Also, is there a case for encouraging the development of these local networks through public funding for farmers' markets, research focusing on small- and mid-scale operations, and attention to the size of operation in the procurement priorities for public institutions?

Food sovereignty, as distinct from food security, has been defined as "the right of nations and peoples to control their own food systems, including their own markets, production modes, food cultures and environments" (147, p. 2). The concept has been defined and advanced most by La Vía Campesina, a transnational peasant social movement, as a way to bring issues of power into the discussion around food policy (148). The concept is a rallying cry for many subsistence-level producers, who have been historically marginalized by the world economy and national policies. Patel (149, p. 122) argues that food sovereignty reflects a desire to regain local control over issues increasingly dictated by global markets; "they want to exercise these rights over the stuff that they need to survive: land, water, seed and culture." Agroecological practices are a pillar of La Via Campesina's "sustainable peasant agriculture." In this vein, Perfecto et al. (150) emphasize that a conservation-oriented ecological agriculture is a key political goal for those promoting food sovereignty. Children of
Agrarian structure: the distribution of farms by size 
indigenous families learn agroecology, together with social organizing skills, at Instituto Universitario Latinoamericano de Agroecología "Paulo Freire" in Barinas, Venezuela (148). Documenting the ripple effects of this type of education is important, as other studies of agroecological farmer-to-farmer learning have shown how these efforts facilitated transformation of agricultural practices, both in developing countries (151) and in the United States (152).

\subsection{Innovation Networks}

Innovation is a central theme in agroecology, and innovative agricultural practices have economic, social, and ecological consequences. Rogers's (153, p. 11) classic "diffusion of innovation" theory defines innovations as an "idea, practice, or object that is perceived as new by an individual or other unit of adoption." Diffusion theory has been applied to thousands of cases $(154,155)$, most notably in the context of the "green revolution," wherein new agricultural practices like fertilizer and pesticides were linked to large-scale increases in agricultural productivity across the world. The general perspective that information regarding costs and benefits of innovations flows through social networks has been shown to apply specifically to agroecological innovation by Warner (152) and others.

The role of social networks continues to be a cutting-edge research topic in diffusion theory; we describe here advancements on several fronts. First, much research in agricultural economics is devoted to uncovering the causal pathways through which social networks influence individual behavior. Manski (156) indicates that the "reflection problem" makes it empirically difficult to determine social influence because social networks consist of likeminded people with similar behavior. Several recent studies have tried to overcome problems of endogeneity and self-selection through research design or statistical methods to isolate the exogenous effects. For example, Conley \& Udry (157) measured social network connec- tivity by asking Ghanaian farmers to identify communication patterns with a set of other farmers randomly selected from a community (also see Reference 158).

A second research front is to determine how different structural characteristics of networks influence behavior. Simple diffusion models are based in a linear imitation model whereby each interaction with another innovation adopter increases the probability of adoption by the focal actor. But Henrich (159) has applied theories of cultural evolution to identify other social learning strategies, such as conformity and prestigebased imitation, which can affect the shape and speed of innovation. This extends earlier work by Burt (160) on innovation behavior that considered differences between networks with many nonredundant ties versus overlapping relationships. The influence of different structural characteristics of networks may depend on adoption characteristics of the individual or the mix of private and social benefits of the innovation. This may be particularly important regarding the diffusion of innovations that provide ecosystem services, which typically involve such a mix of private and social benefits. For some time, there also has been increasing recognition of the knowledge intensity of alternative agricultural practices, which has produced insights regarding knowledge systems in agroecology, particularly the importance of involving stakeholders in research programs (152, $161)$ and of evolving institutional contexts that shape these knowledge systems (162).

Institutions affect the formation of diffusion networks and hence how individuals make decisions about adoption. Pretty (163) reports that thousands of such local partnerships have evolved all over the world in the past two or three decades. The ability of institutions to shape social networks and to influence cooperation and diffusion is particularly important where international agencies are implementing projects to help rural communities improve economic, environmental, and social welfare.

The last topic we consider regarding innovation networks is development of statistical models of diffusion and other social networks. There 
is an ongoing interdisciplinary convergence of network science (164), bringing together social sciences, computer science, physics, and mathematics. A core theme is the development of mathematical models of networks that posit different probability distributions for network formation. For example, the preferential attachment model suggests that the probability of forming a new connection is positively related to existing connections. Mathematical models of innovation diffusion processes have been developed, some closely akin to models of disease spread through social networks (165). The parameters of these models are statistically estimated with empirical data, for example, exponential random graph models (166). Network formation processes have consequences in determining how individuals are embedded in different types of network structures and also on individual behavior. Network science also has important agroecological applications regarding the resilience of cropping systems and biodiversity reserve networks, as well as vulnerability and adaptive capacity in the face of rapid social or environmental change.

\section{DISCUSSION AND PREVIEW OF SOME EMERGING ISSUES}

A central point of this review is that prospects for global change in the twenty-first century have profound implications for agroecology as a means for technological and institutional innovation, adaptive management, and social learning. We now turn our attention to some topics that we believe are particularly important for mitigating environmental impacts of agriculture while increasing global food production and resilience of agriculture and food systems over the coming decades, but these do not appear to have received sufficient attention in the literature on agroecology.

Within the global-change literature, climate change continues to receive considerable attention, along with its implications for the vulnerability of agriculture $(12,167)$, including phenological shifts and disruption of the hydrological cycle (reduced snowpack, greater frequency and severity of droughts and floods).
Regional water imbalances, agrobiodiversity loss, and spread of invasive pests and diseases also are driven by forces quite separate from climate change, as are other social and environmental stressors, such as income growth and changes in food consumption patterns; human population growth, migration, and urbanization; petroleum price shocks; and loading from various pollutants (including $\mathrm{N}$ and $\mathrm{P}$ ). These multifarious drivers of change, which operate at diverse spatial and temporal scales, are likely to increase agricultural production risks and uncertainty over the next four to five decades. At the same time, significant increases in agricultural productivity are required to meet the rising demand for food, feed, and other products $(41,42)$. Measures are needed for "sustainable intensification" of agriculture to raise productivity and simultaneously enhance the resilience of agriculture (41) and land use more generally. This, in turn, requires consideration of both the large perturbations that may cause ecosystem collapse and slower, less-obvious erosion of resilience-such as degradation of pollination services (168)—occurring through cumulative effects of multiple stressors.

\subsection{Agroecology, Global Change, and Human Values}

This review seeks to reframe agroecology within the context of likely global changes and the many drivers affecting agriculture and food systems. We believe that agroecology can help to illuminate the questions raised by emerging global changes and inform efforts necessary to increase productivity and resilience. Some of these contributions likely can be developed through extension of existing agroecological insights. For example, adaptation of IPM practices for agroecological resistance and management of invasive pests and diseases seems to be an urgent priority. Other emerging issues may present deeper challenges to agroecology. Perhaps most fundamental among these is how agroecology can engage different values and ethical systems. In many ways, agroecology has been at the forefront of value-based analysis of agricultural systems 
GMO: genetically modified organism since the 1980s. However, it also must be recognized that academics (including agroecologists) typically find themselves in institutional contexts in which the importance of the values underlying human action is downplayed or avoided. Like any discipline concerned with human-environment interactions, agroecology must grapple with multiple epistemologies $(11,33)$ because emerging challenges are not merely about applying the "right" value system but instead require the ability to bridge different values and interests in seeking workable solutions involving complex trade-offs (32). Moreover, these challenges exist within social structures that disenfranchise some of the most vulnerable groups. For example, the "local food systems" question of what level of self-reliance in food production and distribution optimizes human well-being at what scale (local, regional, national) and over what time period (seasonal, annual, multiple years) depends crucially on how people value the various attributes of food, including their differing views on social and environmental impacts of agricultural production. Similarly, a systematic approach to value systems seems necessary in addressing mounting concerns for animal welfare and the set of interrelated issues surrounding the contributions of intensive livestock production systems to acceleration of antibiotic resistance and GHG emissions. Different values also seem to be at the heart of deep and long-standing disagreements regarding agricultural biotechnology, and this clash of values has obscured other important issues and opportunities. To respond more effectively to these challenges, Lacy et al. (169) argue that social and economic impacts (both positive and negative) should be considered in approval and regulation of agricultural biotechnology. However, these authors also recognize that this "fourth criterion" (in addition to human safety, plant and animal safety, and efficacy) is likely to vary among countries.

\subsection{Agrobiodiversity, Biotechnology, and Genomics}

Modern genetics and biotechnology provide new approaches to understanding and managing a wide range of agroecosystem functions. The complete spectrum of genotype-environment-society relationships illustrates the need to span disciplinary interfaces and is therefore an important consideration for agroecology. To date, however, these relationships have received little integrated attention. Instead, discourse has been dominated by polarizing debates regarding benefits and risks of genetic modification of a few major commercialized species, important controversies regarding intellectual property rights in those genetically modified organisms (GMOs), and rhetoric regarding food security.

Because of this polarization, available studies tend either to emphasize the benefits of agricultural biotechnology (or the opportunity costs of rejecting it), on the one hand, or to focus on the risks, on the other. As a result, integrated appraisals of benefits, costs, risks, and uncertainties of agricultural biotechnology (including but not limited to GMOs) necessary for consideration of its likely effects on agricultural productivity and for addressing plausible concerns regarding the environment, biodiversity (including agrobiodiversity), human health, and food safety are largely lacking. These contending paradigms that divide strategies based on agricultural biotechnology and agroecological approaches have only begun to receive the scientific and ethical attention we believe they deserve $(41,42,170)$. For example, regarding GMOs (but this could be extended to agricultural biotechnology in general), Pretty et al. (42, p. 226) ask:

\footnotetext{
What practical measures are needed to lower ideological barriers between organic and GM, and thus fully exploit the combined potential of both GM crops and organic modes of production in order to achieve agroecological management practices compatible with sustainable intensification of food production?
}

Moreover, we believe this debate-and the science of agroecology-would benefit from a clearer distinction between the application of modern molecular techniques for descriptive 
and analytical purposes versus the use of GMOs, with the latter being the main source of controversy. The distinction is important because the potential benefits, risks, and uncertainties differ dramatically. Current DNA sequencing technologies are revolutionizing biology and the ability to characterize and manage crops and their commensals. Knowing the genome sequences of tomato or wheat or of their microbial associates above- and belowground will provide multiple avenues for improved understanding of agroecosystem functions, all without the risks and uncertainties that accompany release of GMOs.

\subsection{Belowground Agrobiodiversity Management}

It is now feasible to genetically sequence very large numbers of microorganisms, including those that cannot be cultured. Such metagenomic studies will provide breakthroughs in understanding of the functional roles of key microorganisms within agroecosystems. This has not been feasible through classical taxonomic methods because of the overwhelming diversity of microorganisms involved, particularly belowground (but also in and on leaves and other surfaces). Agroecological research needs to anticipate and benefit from this imminent, unprecedented wave of information.

Application of modern tools of genomics over the past decade already has revolutionized description and understanding of belowground biodiversity, including the functional roles of assemblages of microorganisms important to agriculture. This has opened the possibility that we eventually may be able to manage belowground biodiversity as part of agroecological practice $(125,171)$. If that becomes feasible, what might the applications of that knowledge bring? Because soil microorganisms play central roles in many agroecosystem functions, the range of applications is extremely wide. These include soil fertility management; enhanced soil C sequestration, which also reduces GHG emissions (172); biological control of soil pests and diseases; and acceleration of landscape restoration (173).

\subsection{Agricultural Inputs, Farming Practices, and Transitions between Systems}

The National Research Council (174) contrasts a "transformative approach" to agricultural sustainability that applies a broader systems perspective akin to this review with an "incremental approach" that involves relatively small changes in practices within dominant production systems (for example, the gradual substitution of IPM and cover crops for inputs derived from petroleum and natural gas). In a broader context, the scientific debate about whether organic agriculture can meet growing global food needs remains unresolved. Differences in assessments of feasibility of meeting crop $\mathrm{N}$ requirements through biological $\mathrm{N}$ fixation, cover crops, crop rotations, composting, and manure are the crux of this disagreement (175-177). In our view, much more needs to be known about the dynamics and nutrient-use efficiency of various types of fertilizers used individually and also for combinations of organic and synthetic fertilizers; nowhere is this more important than for farming systems in sub-Saharan Africa $(178,179)$.

Even the more modest incremental approach still involves issues worthy of agroecological research, particularly if there are important interactions and thresholds in the transformation of agricultural production systems. Specifically, important interactions across practices and ecosystem services may make it hard to transition incrementally from one system to another and instead require a transformative "jump" involving coordinated changes in a number of practices simultaneously. If this is the case, it would be difficult for farmers to discover a feasible transition path through trial and error. The incremental approach will be even more difficult if those interactions among production practices and ecosystem services are at the landscape or watershed scale, spanning many individual producers. There are a number of production interactions between use of agrochemicals and agroecological practices that could create
Metagenomics: the genomic analysis of all microorganisms present in a specific habitat 
hurdles to an incremental approach, particularly if different farmers are changing practices at different rates or following different trajectories. Market interactions also can contribute barriers to transitions in production systems. For example, the scope for free-range cattle and other (extensive and intensive) systems contributing to meet growing demands for livestock products is limited by low-price (but not necessarily low total cost) competition from CAFOs.

It is worth emphasizing that simple comparisons involving a single attribute (e.g., production costs) easily can produce misleading results by failing to account for trade-offs with other attributes. Valid comparisons of alternative systems typically require careful analysis across a range of possible trade-offs and complementarities. In this context, it also is worth noting a still small, but nevertheless provocative, literature on the differential effects of crop production practices (e.g., organic versus conventional methods) on food quality, nutritional values, and (potentially) human health outcomes (180), which may be linked to $\mathrm{N}$ management as well as other agronomic practices.

\subsection{Resilience and Integration of Production Systems}

The challenges of the twenty-first century are complicated by the fact that what is needed is not a single path but many paths of sustainable intensification (and in some cases deintensification), which are based on a wide range of systems that are appropriate to a very large number of specific agroecological and socioeconomic contexts (42). In response to these challenges, integration (or more accurately reintegration) of production systems offers both significant challenges and opportunities for agroecology. Integrated cropping and mixed-systems options at the field and farm scale are staples of the agroecological literature: fallow rotations, cover crops, permaculture, agroforestry, crop-livestock systems, and even crop-livestock-aquaculture systems. Many of these agroecological approaches hold particular promise as elements of integrated nutrient management strategies (181).

To the extent these systems can reestablish field- and landscape-scale connectivity and diversity, they also may contribute significantly to preserving and restoring wildlife habitat and ecosystem services in agriculture-dominated landscapes. Yet, there also are challenges in efforts to integrate activities at wider scales. Questions have been raised in California about possible trade-offs between habitat preservation and food safety (182). And there are deepseated concerns regarding recycling of urban, rural, and agricultural waste to provide water, nutrients, and energy for agriculture, although it seems likely that these options require serious scientific attention if scarcities of these crucial inputs mount in the decades ahead. Conversely, although the damaging effects of $\mathrm{N}$ fertilizer on coastal fisheries (hypoxia, anoxia, dead zones) are all too familiar, others have raised possibilities of beneficial integration of terrestrial and aquatic production by managing waste from agriculture as inputs to aquaculture systems (41). Because of the complex, interacting, and unprecedented pressures on agriculture and food systems anticipated in the coming decades, we believe the discipline of agroecology has many opportunities to contribute to the search for sustainable solutions by embracing a range of new topics and scales of inquiry, by incorporating insights from global-change science, by interacting and partnering with many different disciplines, and by broadening social engagement to tackle these emerging challenges.

\section{SUMMARY POINTS}

1. Agriculture can be conceptualized within the context of global change and studied as a coupled system that involves a wide range of social and natural processes. 
2. Agricultural production — and hence the field of agroecology—is inextricably linked to the technological, political, economic, social, and cultural aspects of the broader food system.

3. The value of agrobiodiversity to agricultural production levels and to resilience of production systems is well established. Although effective conservation of agrobiodiversity at landscape, regional, and global scales remains a major challenge, agroecology has discovered many practices for the management of agrobiodiversity at the field and farm levels.

4. Substitution of inputs derived from fossil energy (petroleum and natural gas) for some ecosystem services was a key feature of twentieth-century agricultural development, epitomized by contemporary dependency on synthetic $\mathrm{N}$ fertilizer in intensive agricultural systems. Unless alternative nutrient management practices can be expanded dramatically, continuation of business as usual will result in unprecedented $\mathrm{N}$ loading, with adverse environmental consequences.

5. Livestock production increasingly has been decoupled from cropping systems, creating barriers to effective waste management and nutrient cycling. There is little scientific consensus on sustainability of various livestock production systems.

6. Whether or not organic agriculture by itself can meet global food needs remains unresolved; differing assessments of feasibility of meeting $\mathrm{N}$ requirements for crop production through biological $\mathrm{N}$ fixation, cover crops, crop rotations, composting, and manure application are the crux of this debate.

7. Analysis of innovation networks provides key insights on agroecosystem dynamics and on practical approaches to increasing adaptive capacity and resilience in agriculture and the food system.

8. Agroecology has a central role to play in expanding knowledge and awareness of these (and other) aspects of our food and agricultural systems. Because of the complex, interacting, and unprecedented pressures on food and agriculture likely in the coming decades, the discipline of agroecology needs to embrace new topics, scales, and concepts, particularly drawing on global-change science.

\section{FUTURE ISSUES}

1. How can agroecology as a science approach different values and ethical systems, for example, growing public concerns in many countries regarding animal welfare and various aspects of intensive livestock production systems?

2. How can agroecological perspectives contribute to an assessment of the balance of risks and benefits of various applications of agricultural biotechnology for food supply, the environment, human health, and food safety?

3. What level of self-reliance in food production optimizes human well-being at what scale (local, regional, national) and over what time period (seasonal, annual, multiple years)? 
4. How much can integrated cropping systems, such as permaculture and agroforestry, and mixed systems, particularly crop-livestock systems, be developed to substitute for synthetic $\mathrm{N}$ fertilizer, expand global food production (including livestock products), and enhance livelihoods of the poor in developing countries while minimizing environmental degradation and biodiversity loss?

5. What are the most significant relationships between crop production practices, food quality, and human health?

6. How can IPM principles and practices contribute to management of invasive species? And, conversely, how will IPM need to adapt to various aspects of global change?

7. Will it be possible to manage belowground biodiversity as part of an agroecological approach to agriculture? If so, what methods will prove practical?

8. What measures will be most effective in detecting thresholds of concern and in increasing the resilience of agriculture and the food system in the face of multiple drivers of change?

\section{DISCLOSURE STATEMENT}

The authors are not aware of any affiliations, memberships, funding, or financial holdings that might be perceived as affecting the objectivity of this review.

\section{ACKNOWLEDGMENTS}

The authors wish to acknowledge discussion and helpful comments on earlier drafts from Miguel Altieri, Steve Gliessman, Pam Matson, and Damian Parr; suggestions and comments from participants during presentation of this material in the colloquium of the Department of Environmental Science, Policy and Management at the University of California, Berkeley; and facilitation of the review design process by Nancy White.

\section{LITERATURE CITED}

1. Altieri M. 1983. Agroecology: The Scientific Basis of Alternative Agriculture. Berkeley: Div. Biol. Control, Univ. Calif. 162 pp.

2. Altieri M, ed. 1995. Agroecology: The Science of Sustainable Agriculture. Boulder, CO: Westview. 433 pp.

3. Gliessman SR. 2007. Agroecology: The Ecology of Sustainable Food Systems. Boca Raton, FL: CRC Press. $384 \mathrm{pp}$.

4. Vandermeer JH. 2011. The Ecology of Agroecosystems. Sudbury, MA: Jones \& Bartlett. 387 pp.

5. Wezel A, Soldat V. 2009. A quantitative and qualitative historical analysis of the scientific discipline of agroecology. Int. 7. Agric. Sustain. 7(1):3-18

6. Francis C, Lieblein G, Gliessman S, Breland TA, Creamer N, et al. 2003. Agroecology: the ecology of food systems. 7. Sustain. Agric. 22:99-118

7. Lambin EF, Geist HJ, eds. 2006. Land-Use and Land-Cover Change: Local Processes, Global Impacts. Berlin: Springer-Verlag. 222 pp.

8. Giampietro M. 2004. Multi-Scale Integrated Analysis of Agroecosystems. Boca Raton, FL: CRC Press. $437 \mathrm{pp}$.

9. Daily GC, ed. 1997. Nature's Services: Societal Dependence on Natural Ecosystems. Washington, DC: Island. $392 \mathrm{pp}$.

10. Millenn. Ecosyst. Assess. (MA). 2005. Ecosystems and Human Well-being: Synthesis. Washington, DC: Island. $137 \mathrm{pp}$. 
11. Int. Assess. Agric. Knowl. Sci. Technol. Dev. (IAASTD). 2009. Agriculture at a Crossroads: Synthesis Report: A Synthesis of the Global and Sub-Global IAASTD Reports. Washington, DC: Island. 95 pp.

12. Intergov. Panel Clim. Change (IPCC). 2007. Climate Change 2007: Synthesis Report. Contribution of Working Groups I, II and III to the Fourth Assessment Report of the Intergovernmental Panel on Climate Change (Core Writ. Team, RK Pachauri, A Reisinger, eds.). Geneva, Switz.: IPCC. 104 pp.

13. Compr. Assess. Water Manag. Agric. 2007. Water for Food, Water for Life: A Comprehensive Assessment of Water Management in Agriculture. London: Earthscan. 645 pp.

14. Rosegrant MW, Ringler C, Zhu T. 2009. Water for agriculture: maintaining food security under growing scarcity. Annu. Rev. Environ. Resour. 34:205-22

15. Jackson ST, Hobbs RJ. 2009. Ecological restoration in the light of ecological history. Science 325:567-69

16. Turner MG. 2005. Landscape ecology: What is the state of the science? Annu. Rev. Ecol. Evol. Syst. 36:319-44

17. Kremen C. 2005. Managing ecosystem services: What do we need to know about their ecology? Ecol. Lett. 8(5):468-79

18. Ahrens TD, Beman JM, Harrison JA, Jewett PK, Matson PA. 2008. A synthesis of nitrogen transformations and transfers from land to sea in the Yaqui Valley agricultural region of northwest Mexico. Water Resour. Res. 44:W00A05

19. Nelson E, Mendoza G, Regetz J, Polasky S, Tallis H, et al. 2009. Modeling multiple ecosystem services, biodiversity conservation, commodity production, and tradeoffs at landscape scales. Front. Ecol. Environ. 7(1):4-11

20. Pretty JN. 2008. Agricultural sustainability: concepts, principles, and evidence. Philos. Trans. R. Soc. B $363: 447-65$

21. Moran EF. 2010. Environmental Social Science: Human-Environment Interactions and Sustainability. Malden, MA: Wiley-Blackwell

22. Dillard JF, Dujon V, King MC. 2009. Understanding the Social Dimension of Sustainability. New York: Routledge

23. Levins RA. 2009. Why don't we have sustainable agriculture now? Shivvers Memorl. Lect. Ames, IA: Leopold Cent. Sustain. Agric.

24. Guthman J. 2004. Agrarian Dreams: The Paradox of Organic Farming in California. Berkeley: Univ. Calif. Press. 250 pp.

25. Getz C, Brown S, Shreck A. 2008. Class politics and agricultural exceptionalism in California's organic agriculture movement. Polit. Soc. 36(4):478-507

26. Brauman KA, Daily GC, Duarte TK, Mooney HA. 2007. The nature and value of ecosystem services: an overview highlighting hydrological services. Annu. Rev. Environ. Resour. 32:67-98

27. Bennett EM, Peterson GD, Gordon LJ. 2009. Understanding relationships among multiple ecosystem services. Ecol. Lett. 12:1-11

28. Dale VH, Polasky S. 2007. Measures of the effects of agricultural practices on ecosystem services. Ecol. Econ. 64(2):286-96

29. Wright W, Middendorf G, eds. 2008. The Fight over Food: Producers, Consumers, and Activists Challenge the Global Food System. University Park: Penn. State Univ. Press

30. Magis K, Shinn C. 2009. Emergent principles of social sustainability. See Ref. 22, pp. 15-44

31. Sen A. 2009. The Idea of fustice. Cambridge, MA: Harvard Univ. Press. 468 pp.

32. Clark WC, Tomich TP, van Noordwijk M, Guston D, Catacutan D, et al. 2011. Boundary work for sustainable development: natural resource management at the consultative group on international agricultural research (CGIAR). Proc. Natl. Acad. Sci. USA 10.1073/pnas.0900231108

33. Ash N, Blanco H, Brown C, Garcia K, Henrichs T, et al. eds. 2010. Ecosystems and Human Well-being: A Manual for Assessment Practitioners. Washington, DC: Island. 264 pp.

34. Liu J, Dietz T, Carpenter SR, Alberti M, Folke C, et al. 2007. Complexity of coupled human and natural systems. Science 317(5844):1513-16

35. Turner BL II, Lambin EF, Reenberg A. 2007. The emergence of land change science for global environmental change and sustainability. Proc. Natl. Acad. Sci. USA 104(52):20666-71

36. Robertson GP, Swinton SM. 2005. Reconciling agricultural productivity and environmental integrity: a grand challenge for agriculture. Front. Ecol. Environ. 3:38-46 
37. Brondizio ES, Ostrom E, Young OR. 2009. Connectivity and the governance of multilevel socialecological systems: the role of social capital. Annu. Rev. Environ. Resour. 34:253-78

38. Elmqvist T, Folke C, Nystrom M, Peterson G, Bengtsson J, et al. 2003. Response diversity, ecosystem change, and resilience. Front. Ecol. Environ. 1:488-94

39. Darnhofer I, Fairweather J, Moller H. 2010. Assessing a farm's sustainability: insights from resilience thinking. Int. F. Agric. Sustain. 8(3):186-98

40. Lebel L, Anderies JM, Campbell B, Folke C, Hatfield-Dodds S, et al. 2006. Governance and the capacity to manage resilience in regional social-ecological systems. Ecol. Soc. 11(1):19. http://www.ecologyandsociety.org/vol11/iss1/art19/

41. Godfray HCJ, Beddington JR, Crute IR, Haddad L, Lawrence D, et al. 2010. Food security: the challenge of feeding 9 billion people. Science 327(5967):812-18

42. Pretty JN, Sutherland WJ, Ashby J, Auburn J, Baulcombe D, et al. 2010. The top 100 questions of importance to the future of global agriculture. Int. F. Agric. Sustain. 8(4):219-36

43. Norton DA. 2009. Species invasions and the limits to restoration: learning from the New Zealand experience. Science 325:569-71

44. Sachs JD, Remans R, Smuckler S, Winowiecki L, Andelman SJ, et al. 2010. Monitoring the world's agriculture. Nature 466(29):558-60

45. Reid WV, Chen D, Goldfarb L, Hackmann H, Lee YT, et al. 2010. Earth system science for global sustainability: grand challenges. Science 330:916-17

46. Rockstrom J, Steffen W, Noone K, Persson A, Chapin FS III, et al. 2009. Planetary boundaries: exploring the safe operating space for humanity. Ecol. Soc. 14(2):32. http://www. ecologyandsociety.org/vol14/iss2/art32/

47. Scherr SJ, McNeely JA, eds. 2007. Farming with Nature: The Science and Practice of Ecoagriculture. Washington, DC: Island. 445 pp.

48. Palm CA, Vosti SA, Sanchez PA, Ericksen PJ, eds. 2005. Slash-and-Burn Agriculture: The Search for Alternatives. New York: Columbia Univ. Press. 463 pp.

49. DeClerck FR, Chazdon R, Holl K, Milder B, Finegan B, et al. 2010. Biodiversity conservation in humanmodified landscapes of Mesoamerica: past, present, and future. Biol. Conserv. 143:2301-13

50. Harvey CA, Komar O, Chazdon R, Ferguson BG, Finnegan B, et al. 2008. Integrating agricultural landscapes with biodiversity conservation in the Mesoamerican hotspot. Conserv. Biol. 22:8-15

51. Pretty J, Toulmin C, Williams S. 2011. Sustainable intensification in African agriculture (Special issue: Sustainable intensification: increasing productivity in African food and agricultural systems). Int. 7. Agric. Sustain. 9(1):5-24

52. Garrity DP, Akinnifesi FK, Ajayi OC, Weldesemayat SG, Mowo JG, et al. 2010. Evergreen agriculture: a robust approach to sustainable food security in Africa. Food Secur. 2:197-214

53. Tomich TP, van Noordwijk M, Thomas DE, eds. 2004. Environmental services and land use change: bridging the gap between policy and research in Southeast Asia. Special issue Agric. Ecosyst. Environ. 104(1). 244 pp.

54. Zimmerer K. 2010. Biological diversity in agriculture and global change. Anпи. Rev. Environ. Resour. 35:137-66

55. Naylor RL, Steinfeld H, Falcon W, Galloway J, Smil V, et al. 2005. Agriculture: losing the links between livestock and land. Science 310(5754):1621-22

56. Smukler SM, Sánchez-Moreno S, Fonte SJ, Ferris H, Klonsky K, et al. 2010. Biodiversity and multiple ecosystem functions in an organic farmscape. Agric. Ecosyst. Environ. 139:80-97

57. Brussaard L, de Ruiter PC, Brown GG. 2007. Soil biodiversity for agricultural sustainability. Agric. Ecosyst. Environ. 121:233-44

58. Gurr GM, Wratten SD, Luna JM. 2003. Multi-function agricultural biodiversity: pest management and other benefits. Basic Appl. Ecol. 4:107-16

59. Tilman D. 1996. Biodiversity: population versus ecosystem stability. Ecology 77:350-63

60. Loreau M, Naeem S, Inchausti P, Bengtsson J, Grime JP, et al. 2001. Biodiversity and ecosystem functioning: current knowledge and future challenges. Science 294:804-8

61. Jackson LE, Pascual U, Hodgkin T. 2007. Utilizing and conserving agrobiodiversity in agricultural landscapes. Agric. Ecosyst. Environ. 121:196-210 
62. Hiddink GA, Termorshuizen AJ, van Bruggen AHC. 2010. Mixed cropping and suppression of soilborne diseases. Sustain. Agric. Rev. 4:119-46

63. Tscharntke T, Klein AM, Steffan-Dewenter I, Thies C. 2005. Landscape perspectives on agricultural intensification and biodiversity-ecosystem service management. Ecol. Lett. 8: 857-74

64. Khoshbakht K, Hammer K. 2008. How many plant species are cultivated? Genet. Resour. Crop. Evol. 55:925-28

65. Prescott-Allen R, Prescott-Allen C. 1990. How many plants feed the world? Conserv. Biol. 4:365-74

66. Shea K, Chesson P. 2002. Community ecology theory as a framework for biological invasions. Trends Ecol. Evol. 17:170-76

67. Colautti RI, MacIsaac HJ. 2004. A neutral terminology to define 'invasive species.' Divers. Distrib. 10:13541

68. Jeschke JM, Strayer DL. 2005. Invasion success of vertebrates in Europe and North America. Proc. Natl. Acad. Sci. USA 102:7198-202

69. Cook SM, Khan ZR, Pickett JA. 2007. The use of push-pull strategies in integrated pest management. Annu. Rev. Entomol. 52:375-400

70. Kremen C, Williams NM, Thorp RW. 2002. Crop pollination from native bees at risk from agricultural intensification. Proc. Natl. Acad. Sci. USA 99:16812-16

71. Klein A-M, Cunningham SA, Bos M, Steffan-Dewenter I. 2008. Advances in pollination ecology from tropical plantation crops. Ecology 89:935-43

72. Winfree R, Aguilar R, Vázquez DP, LeBuhn G, Aizen MA. 2009. How do bees respond to anthropogenic disturbance? A meta-analysis. Ecology 90:2068-76

73. Williams NM, Kremen C. 2007. Resource distributions among habitats determine solitary bee offspring production in a mosaic landscape. Ecol. Appl. 17:910-21

74. Westphal C, Steffan-Dewenter I, Tscharntke T. 2003. Mass flowering crops enhance pollinator densities at a landscape scale. Ecol. Lett. 6:961-65

75. Rundlof M, Nilsson H, Smith HG. 2008. Interacting effects of farming practice and landscape context on bumble bees. Biol. Conserv. 141:417-26

76. Shuler R, Roulston TH, Farris GE. 2005. Farming practices influence wild pollinator populations on squash and pumpkin. 7. Econ. Entomol. 98:790-95

77. Kim J, Williams N, Kremen C. 2006. Effects of cultivation and proximity to natural habitat on groundnesting native bees in California sunflower fields. F. Kans. Entomol. Soc. 79:309-20

78. Pulliam RH. 1988. Sources, sinks, and population regulation. Am. Nat. 132:652-61

79. Tenuta M, Ferris H. 2004. Relationship between nematode life-history classification and sensitivity to stressors: ionic and osmotic effects of nitrogenous solutions. F. Nematol. 36:85-94

80. Yeates GW, Ferris H, Moens T, Van der Putten WH. 2009. The role of nematodes in ecosystems. In Nematodes as Environmental Bioindicators, ed. MJ Wilson, T Kakouli-Duarte, 1:1-44. Wallingford, UK: CAB Int.

81. Bongers T, Ferris H. 1999. Nematode community structure as a bioindicator in environmental monitoring. Trends Evol. Ecol. 14:224-28

82. Minoshima H, Jackson LE, Cavagnaro TR, Sánchez-Moreno S, Ferris H, et al. 2007. Soil food webs and carbon dynamics in response to conservation tillage in California. Soil Sci. Soc. Am. 7. 71:952-63

83. Sánchez-Moreno S, Nicola NL, Ferris H, Zalom FG. 2009. Effects of agricultural management on nematode-mite assemblages: soil food web indices as predictors of mite community composition. Appl. Soil Ecol. 41:107-17

84. Ferris H, Bongers T. 2006. Nematode indicators of organic enrichment. 7. Nematol. 38:3-12

85. Jensen HJ, Mulvey RH. 1968. Predaceous nematodes (Mononchidae) of Oregon. Oreg. State Monogr. 12:1-57

86. Bilgrami AL, Gaugler R, Brey C. 2005. Prey preference and feeding behaviour of the diplogastrid predator Mononchoides gaugleri (Nematoda: Diplogasetrida). Nematology 7:333-42

87. Garrett KA, Mundt CC. 2000. Host diversity can reduce potato late blight severity for focal and general patterns of primary inoculum. Phytopathology 90:1307-12

88. Kokalis-Burelle N, Kloepper JW, Reddy MS. 2006. Plant growth-promoting rhizobacteria as transplant amendments and their effects on indigenous rhizosphere microorganisms. Appl. Soil Ecol. 31:91-100 
89. Douds DD Jr, Nagahashi G, Pfeffer PE, Kayser WM, Reider C. 2005. On-farm production and utilization of arbuscular mycorrhizal fungus inoculum. Can. 7. Plant Sci. 85:15-21

90. Lu YC, Teasdale JR, Huang WY. 2003. An economic and environmental tradeoff analysis of sustainable agriculture cropping systems. 7. Sustain. Agric. 22:25-41

91. Ladha JK, Pathak H, Krupnik TJ, Six J, van Kessel C. 2005. Efficiency of fertilizer nitrogen in cereal production: retrospects and prospects. Adv. Agron. 87:85-156

92. Robertson GP, Vitousek PM. 2009. Nitrogen in agriculture: balancing the cost of an essential resource. Annu. Rev. Environ. Resour. 34:97-125

93. Bouwman AF, Beusen AHW, Billen G. 2009. Human alteration of the global nitrogen and phosphorus soil balances for the period 1970 to 2050. Glob. Biogeochem. Cycles 23:GB0A04

94. Erisman JW, Sutton MA, Galloway J, Klimont Z, Winiwarter W. 2008. How a century of ammonia synthesis changed the world. Nat. Geosci. 1:636-39

95. Gilbert N. 2009. The disappearing nutrient. Nature 461:716-18

96. Searchinger T, Heimlich R, Houghton RA, Dong F, Elobeid A, et al. 2008. Use of U.S. croplands for biofuels increases greenhouse gases through emissions from land-use change. Science 319:1238-40

97. Antle JM, Capalbo SM, Paustian K, Ali MK. 2007. Estimating the economic potential for agricultural soil carbon sequestration in the central United States using an aggregate econometric-process simulation model. Clim. Change 80:145-71

98. Howitt RE, Catala-Luque R, De Gryze S, Wicks S, Six J. 2009. Realistic payments could encourage farmers to adopt practices that sequester carbon. Calif. Agric. 63:91-95

99. Durandeau S, Gabrielle S, Godard C, Jayet P-A, Le Bas C. 2010. Coupling biophysical and microeconomic models to assess the effect of mitigation measures on greenhouse gas emissions from agriculture. Clim. Change 98:51-73

100. Kebreab E, Dijkstra J, Bannink A, France J. 2009. Recent advances in modeling nutrient utilization in ruminants. F. Anim. Sci. 87(Suppl. 14):E111-22

101. Kebreab E, Strathe AB, Yitbarek A, Nyachoti CM, Dijkstra J, et al. 2011. Modeling the efficiency of phosphorus utilization in growing pigs. 7. Anim. Sci. In press

102. Steinfeld H, Wassenaar T. 2007. The role of livestock production in carbon and nitrogen cycles. Annu. Rev. Environ. Resour. 32:271-94

103. Food Agric. Organ. (FAO). 2006. Livestock's Long Shadow. Rome, Italy: UN FAO

104. Pitesky ME, Stackhouse KR, Mitloehner FM. 2009. Clearing the air: livestock's contribution to climate change. Adv. Agron. 103:1-40

105. Pelletier N, Pirog R, Rasmussen R. 2010. Comparative life cycle environmental impacts of three beef production strategies in the Upper Midwestern United States. Agric. Syst. 103:380-89

106. Peters GM, Rowley HV, Wiedemann S, Tucker R, Short MD, Schulz M. 2010. Red meat production in Australia: life cycle assessment and comparison with overseas studies. Environ. Sci. Tecbnol. 44:1327-32

107. Beauchemin KA, Kreuzer M, O’Mara F, McAlister TA. 2008. Nutritional management for enteric methane abatement: a review. Aust. F. Exp. Agric. 48(2):21-27

108. Herrero M, Thornton PK, Notenbaert AM, Wood S, Msangi S, et al. 2010. Smart investments in sustainable food production: revisiting mixed crop-livestock systems. Science 327:822-25

109. Gill M, Smith P, Wilkinson JM. 2010. Mitigating climate change: the role of domestic livestock. Animal 4:323-33

110. McEwen SA, Fedorka-Cray J. 2002. Antimicrobial use and resistance in animals. Clin. Infect. Dis. 34(Suppl. 3):S93-106

111. Catry B, Haesebrouck F, De Vliegher S, Feyen B, Van Robaeys M, et al. 2005. Variability in acquired resistance of Pasteurella and Mannheimia isolates from the nasopharynx of calves, with particular reference to different herd types. Microb. Drug Resist. 11:387-94

112. Duff GC, Galyean ML. 2007. Board-invited review: recent advances in management of highly stressed, newly received feedlot cattle. F. Anim. Sci. 85:823-40

113. Summers AO. 2002. Generally overlooked fundamentals of bacterial genetics and ecology. Clin. Infect. Dis. 34(Suppl. 3):S85-92

114. Barza MS, Gorbach S, DeVincent SJ. 2002. The need to improve antimicrobial use in agriculture: ecological and human health consequences. Clin. Infect. Dis. 34(Suppl. 3):S71-72 
115. Chapin FS III, Matson P, Mooney HA. 2002. Principles of Terrestrial Ecosystem Ecology. New York: Springer. 436 pp.

116. Vitousek PM, Naylor R, Crews T, David MB, Drinkwater LE, et al. 2009. Nutrient imbalances in agricultural development. Science 324:1519-20

117. Tilman D, Cassman KG, Matson PA, Naylor R, Polasky S. 2002. Agricultural sustainability and intensive production practices. Nature 418:671-77

118. Galloway JN, Cowling EB. 2002. Reactive nitrogen and the world: 200 years of change. AMBIO 31(2):6471

119. Gordon LJ, Peterson GD, Bennett EM. 2008. Agricultural modifications of hydrological flows create ecological surprises. Trends Ecol. Evol. 23:211-19

120. Jackson LE, Rosenstock TS, Thomas MA, Wright J, Symstad A. 2009. Managed ecosystems: biodiversity and ecosystem functions in landscapes modified by human use. In Biodiversity, Ecosystem Functioning, and Human Wellbeing: An Ecological and Economic Perspective, ed. S Naeem, DE Bunker, A Hector, M Loreau, C Perrings, 13:178-94. New York: Oxford Univ. Press. 384 pp.

121. Robertson GP, Allen VG, Boody G, Boose ER, Creamer NG, et al. 2008. Long-term agricultural research: a research, education, and extension imperative. BioScience 58:640-43

122. Robertson GP, Broome JC, Chornesky EA, Frankenberger JR, Johnson P, et al. 2004. Rethinking the vision for environmental research in US agriculture. BioScience 54:61-65

123. Wardle DA, Bardgett RD, Klironomos JN, Setala H, van der Putten WH, Wall DH. 2004. Ecological linkages between aboveground and belowground biota. Science 304:1629-33

124. Gianinazzi S, Gollotte A, Binet M-N, van Tuinen D, Redecker D, Wipf D. 2010. Agroecology: the key role of arbuscular mycorrbizas in ecosystem services. Mycorrbiza 20:519-30

125. Barrios E. 2007. Soil biota, ecosystem services, and land productivity. Ecol. Econ. 64:269-85

126. Drinkwater LE, Snapp SS. 2007. Nutrients in agriculture: rethinking the management paradigm. Adv. Agron. 92:163-86

127. Tonitto C, David MB, Drinkwater LE. 2006. Replacing bare fallows with cover crops in fertilizerintensive cropping systems: a meta-analysis of crop yield and N dynamics. Agric. Ecosyst. Environ. 112:58 72

128. Poudel DD, Ferris H, Klonsky K, Horwath WR, Scow KM, et al. 2001. The sustainable agriculture farming system project in California's Sacramento Valley. Outlook Agric. 30(2):109-16

129. Moss B. 2008. Water pollution by agriculture. Philos. Trans. R. Soc. B 363:659-66

130. Gascuel-Odoux C, Massa F, Durand P, Merot P, Troccaz O, et al. 2008. Framework and tools for agricultural landscape assessment relating to water quality protection. Environ. Manag. 43(5):921-35

131. David MB, Drinkwater LE, McIsaac GF. 2010. Sources of nitrate yields in the Mississippi River Basin. 7. Environ. Qual. 39:1657-67

132. Galloway JN, Townsend AR, Erisman JW, Bekunda M, Cai ZC, et al. 2008. Transformation of the nitrogen cycle: recent trends, questions, and potential solutions. Science 320:889-92

133. Sims JT, Bergstrom L, Bowman BT, Oenema O. 2005. Nutrient management for intensive animal agriculture: policies and practices for sustainability. Soil Use Manag. 21:141-51

134. Pang XP, Letey J. 2000. Organic farming: challenge of timing nitrogen availability to crop nitrogen requirements. Soil Sci. Soc. Am. F. 64:247-53

135. Kinney C, Furlong E, Zaugg S, Burkhardt M, Werner S, et al. 2006. Survey of organic wastewater contaminants in biosolids destined for land application. Environ. Sci. Technol. 40:7207-15

136. Allen P. 2010. Realizing justice in local food systems. Camb. F. Reg. Econ. Soc. 3(2):295-308

137. Allen P. 2004. Together at the Table: Sustainability and Sustenance in the American Agrifood System. University Park: Penn. State Univ. Press

138. McClintock N. 2010. Why farm the city? Theorizing urban agriculture through a lens of metabolic rift. Camb. 7. Reg. Econ. Soc. 3(2):191-207

139. Quandt SA, Shoaf JI, Tapia J, Hernández-Pelletier M, Clark HM, Arcury TA. 2006. Experiences of Latino immigrant families in North Carolina help explain elevated levels of food insecurity and hunger. 7. Nutr. 136(10):2638-44 
140. Weigel MM, Armijos RX, Hall YP, Ramirez Y, Orozco R. 2007. The household food insecurity and health outcomes of U.S.-Mexico border migrant and seasonal farmworkers. F. Immigr. Minor. Health 9(3):157-69

141. Nord M, Coleman-Jensen A, Andrews M, Carlson S. 2010. Household Food Security in the United States, 2009. Washington, DC: Econ. Res. Serv., USDA

142. Bacon CM, Méndez EV, Flores Gómez ME, Stuart D, Díaz Flores SR. 2008. Are sustainable coffee certifications enough to secure farmer livelihoods? The Millenium Development Goals and Nicaragua's fair trade cooperatives. Globalizations 5(2):259-74

143. Pirog R, Benjamin A. 2003. Checking the Food Odometer: Comparing Food Miles for Local Versus Conventional Produce Sales to Iowa Institutions. Ames, IA: Leopold Cent. Sustain. Agric.

144. Smith A, Watkiss P, Tweddle G, McKinnon A, Browne M, et al. 2005. The validity of food miles as an indicator of sustainable development. Final Rep., Iss. 7. Dep. Environ. Food, Rural Aff., London, UK

145. Weber CL, Matthews HS. 2008. Food-miles and the relative climate impacts of food choices in the United States. Environ. Sci. Technol. 42(10):3508-13

146. Pelletier N, Audsley E, Brodt S, Garnett T, Henriksson P, et al. 2011. Energy intensity of agriculture and food systems. Annu. Rev. Environ. Resour. 36:223-46

147. Wittman H, Desmarais AA, Wiebe N, eds. 2010. Food Sovereignty: Reconnecting Food, Nature and Community. Oakland, CA: Food First Books

148. Martinez-Torres ME, Rosset PM. 2010. La Via Campesina: the birth and evolution of a transnational social movement. 7. Peasant Stud. 37(1):149-75

149. Patel R. 2010. The Value of Nothing: How to Reshape Market Society and Redefine Democracy. New York: Picador

150. Perfecto I, Vandermeer JH, Wright AL. 2009. Nature's Matrix: Linking Agriculture, Conservation and Food Sovereignty. Sterling, VA: Earthscan. 272 pp.

151. Holt-Gimenez E. 2006. Campesino a Campesino: Voices from Latin America's Farmer to Farmer Movement for Sustainable Agriculture. Oakland, CA: Food First Books

152. Warner KD. 2007. Agroecology in Action: Extending Alternative Agriculture through Social Networks. Cambridge, MA: MIT Press. 273 pp.

153. Rogers E. 2003. Diffusion of Innovations. New York: Free Press

154. Feder G, Umali DL. 1993. The adoption of agricultural innovations: a review. Technol. Forecast. Soc. Change 43(3/4):215-39

155. Wejnert B. 2002. Integrating models of diffusion of innovations: a conceptual framework. Anпu. Rev. Sociol. 28(1):297-326

156. Manski CF. 1993. Identification of endogenous social effects: the reflection problem. Rev. Econ. Stud. 60(3):531-42

157. Conley TG, Udry CR. 2001. Social learning through networks: the adoption of new agricultural technologies in Ghana. Am. 7. Agric. Econ. 83(3):668-73

158. Bandiera O, Rasul I. 2006. Social networks and technology adoption in Northern Mozambique. Econ. 7 . 116(514):869-902

159. Henrich J. 2001. Cultural transmission and the diffusion of innovations: Adoption dynamics indicate that biased culture transmission is the predominate force in behavioral change. Am. Anthropol. 103(4):9921013

160. Burt RS. 1987. Social contagion and innovation—cohesion versus structural equivalence. Am. F. Sociol. 92(6): $1287-335$

161. Kristjanson P, Reid R, Dickson N, Clark WC, Romney D, et al. 2009. Linking international agricultural research knowledge with action for sustainable development. Proc. Natl. Acad. Sci. USA 106(13):5047-52

162. McCullough EB, Matson PA. 2011. Evolution of the knowledge system for agricultural development in the Yaqui Valley, Sonora, Mexico. Proc. Natl. Acad. Sci. USA doi:10.1073/pnas.10,11602108

163. Pretty JN. 2003. Social capital and the collective management of resources. Science 302 (5652):1912-14

164. Newman M. 2010. Networks: An Introduction. Oxford, UK: Oxford Univ. Press

165. Valente TW. 1996. Social network thresholds in the diffusion of innovations. Soc. Netw. 181:69-89

166. Robins G, Pattison P, Kalish Y, Lusher D. 2007. An introduction to exponential random graph ( $\left.\mathrm{p}^{*}\right)$ models for social networks. Soc. Netw. 29(2):173-91 
167. Lobell DB, Burke MB, Tebaldi C, Mastrandea MD, Falcon WP, Naylor RL. 2008. Prioritizing climate change adaptation needs for food security to 2030. Science 319:607-10

168. Gallai N, Salles JM, Settele J, Vaissioin BE. 2009. Economic valuation of the vulnerability of world agriculture confronted with pollinator decline. Ecol. Econ. 68(3):810-21

169. Lacy WB, Glenna L, Biscotti D, Welsh R. 2010. Agricultural biotechnology, socioeconomic effects, and the fourth criterion. In Encyclopedia of Industrial Biotechnology, Bioprocess, Bioseparation, and Cell Technology, ed. MC Flickinger, pp. 1-16. Hoboken, NJ: Wiley

170. Ronald PC, Adamchak RW. 2008. Tomorrow's Table: Organic Farming, Genetics, and the Future of Food. New York: Oxford Univ. Press

171. Natl. Res. Counc. (NRC). 2009. Frontiers in Soil Science Research: Report of a Workshop. Washington, DC: Natl. Acad. Press. 68 pp.

172. Six J, Frey SD, Thiet RK, Batten KM. 2006. Bacterial and fungal contributions to carbon sequestration in agroecosystems. Soil Sci. Soc. Am. 7. 70:555-69

173. Harris J. 2009. Soil microbial communities and restoration ecology: facilitators or followers? Science 325:573-74

174. Natl. Res. Counc. (NRC). 2010. Toward Sustainable Agricultural Systems in the $21^{\text {st }}$ Century. Washington, DC: Natl. Acad. Press. 570 pp.

175. Badgley C, Moghtader J, Quintero E, Zakem E, Chappell MJ, et al. 2007. Organic agriculture and the global food supply. Renew. Agric. Food Syst. 22(2):86-108

176. Cassman K. 2007. Editorial response: Can organic agriculture feed the world? Renew. Agric. Food Syst. 22(2):83-84

177. Kirchmann H, Bergstrom L, eds. 2008. Organic Crop Production—Ambitions and Limitations. New York: Springer. 244 pp.

178. Chivenge P, Vanlauwe B, Six J. 2011. Does the combined application of organic and mineral nutrient sources influence maize productivity? A meta-analysis. Plant Soil 342:1-30

179. Vanlauwe B, Kihara J, Chivenge P, Pypers P, Coe R, Six J. 2011. Agronomic use efficiency of N fertilizer in maize-based systems in sub-Saharan Africa within the context of integrated soil fertility management. Plant Soil 339:35-50

180. Reganold JP, Andrews PK, Reeve JR, Carpenter-Boggs L, Schadt CW, et al. 2010. Fruit and soil quality of organic and conventional strawberry agroecosystems. PLOS ONE 5(9):e12346

181. Kramer SB, Reganold JP, Glover JD, Bohannan BJM, Mooney HA. 2006. Reduced nitrate leaching and enhanced denitrifier activity and efficiency in organically fertilized soils. Proc. Natl. Acad. Sci. USA 103(12):4522-27

182. Beretti M, Stuart D. 2008. Food safety and environmental quality impose conflicting demands on Central Coast growers. Calif. Agric. 62(2):68-73

\section{RELATED RESOURCES}

Literature in Spanish and Portuguese: Latin American scholars have produced a large, formative, and dynamic literature on agroecology as a science, a body of practices, and a social movement. Important contributions by Altieri, Astier, Caporal, Gliessman, Holt-Gimenez, Leon, Sevilla Guzman, Toledo, and other leading scholars can be accessed through the Web site for the Latin American Society of Agroecology (SOCLA). http://www.agroeco.org/socla/

Agricultural biotechnology: Herdt RW. 2006. Biotechnology in agriculture. Annu. Rev. Environ. Resour. 31:265-95

Agroecosystem assessment: Wood S, Sebastian K, Scherr SJ. 2000. Pilot Analysis of Global Ecosystems: Agroecosystems. Washington, DC: Int. Food Policy Res. Inst./World Resour. Inst.

Aquaculture: Holmer M, Black K, Duarte CM, Marba N, Karakassis I, eds. 2008. Aquaculture in the Ecosystem. Berlin: Springer, 326 pp.

Biofuels: Sagar AD, Kartha S. 2007. Bioenergy and sustainable development? Annu. Rev. Environ. Resour. 32:131-67 
Crop yields: Lobell DB, Cassman KG, Field CB. 2009. Crop yield gaps: their importance, magnitudes, and causes. Annu. Rev. Environ. Resour. 34:179-204

Soils: Palm C, Sanchez P, Ahamed S, Awiti A. 2007. Soils: a contemporary perspective. Annu. Rev. Environ. Resour. 32:99-129

Resilience: Nelson DR, Adger WN, Brown K. 2007. Adaptation to environmental change: contributions of a resilience framework. Annu. Rev. Environ. Resour. 32:395-419

Vulnerability: Eakin H, Luers AL. 2006. Assessing the vulnerability of social-environmental systems. Annu. Rev. Environ. Resour. 31:365-94 